\title{
The Northeast Asia mountain glaciers in the near future by AOGCM scenarios
}

\author{
M. D. Ananicheva ${ }^{1}$, A. N. Krenke ${ }^{1}$, and R. G. Barry ${ }^{2}$ \\ ${ }^{1}$ Institute of Geography, Russian Academy of Sciences, Moscow, 119017, Russia \\ ${ }^{2}$ National Snow and Ice Data Center, CIRES, University of Colorado, Boulder, CO 80309, USA \\ Received: 31 March 2010 - Published in The Cryosphere Discuss.: 18 May 2010 \\ Revised: 13 September 2010 - Accepted: 18 September 2010 - Published: 6 October 2010
}

\begin{abstract}
We studied contrasting glacier systems in continental (Orulgan, Suntar-Khayata and Chersky) mountain ranges, located in the region of the lowest temperatures in the Northern Hemisphere at the boundary of Atlantic and Pacific influences - and maritime ones (Kamchatka Peninsula) - under Pacific influence. Our purpose is to present a simple projection method to assess the main parameters of these glacier regions under climate change. To achieve this, constructed vertical profiles of mass balance (accumulation and ablation) based both on meteorological data for the 19501990s (baseline period) and ECHAM4 for 2049-2060 (projected period) are used, the latter - as a climatic scenario. The observations and scenarios were used to define the recent and future equilibrium line altitude and glacier terminus altitude level for each glacier system as well as areas and balance components. The altitudinal distributions of ice areas were determined for present and future, and they were used for prediction of glacier extent versus altitude in the system taking into account the correlation between the ELA and glacier-terminus level change. We tested two hypotheses of ice distribution versus altitude in mountain (valley) glaciers "linear" and "non-linear". The results are estimates of the possible changes of the areas and morphological structure of northeastern Asia glacier systems and their mass balance characteristics for 2049-2060. Glaciers in the southern parts of northeastern Siberia and those covering small ranges in Kamchatka will likely disappear under the ECHAM4 scenario; the best preservation of glaciers will be on the highest volcanic peaks of Kamchatka. Finally, we compare characteristics of the stability of continental and maritime glacier systems under global warming.
\end{abstract}

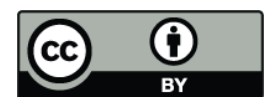

Correspondence to: $\mathrm{M}$. Ananicheva (maria_anan@rambler.ru)

\section{Introduction}

Our approach involves the projection of (1) equilibrium line altitude (ELA) because at this level it is possible to reconstruct accumulation by calculated ablation due to their equality here (e.g. Braithwaite and Raper, 2007), and (2) glacier terminus altitude because this is correlated with ELA change (e.g. Chinn et al., 2005). The projected ELA can be obtained as the intersection of the accumulation and ablation balance profiles for glacier systems (regions). To project glacier change, not only in the case of individual glaciers but also for groups of them (glacier systems), is an important goal in global environmental change studies (e.g. Dowdeswell and Hagen, 2004). The term "glacier system" is considered as a set of glaciers united by their common links with the environment: the same mountain system or archipelago location and similar atmospheric circulation patterns. The glaciers are related to each other usually by parallel links from atmospheric inputs and topographical forms to hydrological and topographical outputs, and demonstrate common spatial regularities of glacier regime and other features. For each glacier system the balance scheme (accumulation and ablation vertical profiles) is constructed from climate data.Here we present a simple method for projection of change of the glacier systems' parameters and the application of this method for the region of northeastern Asia. We have chosen to study the continental glacier systems of northeastern Siberia-Orulgan (a part of Verkhonyansky Range in Fig. 1), the SuntarKhayata and Chersky ranges - and the maritime glacier systems of Kamchatka-Sredinniy and Kronotsky ranges, and the Kluchevskaya, Tolbechek, Chiveluch volcano groups (see Fig. 1 and Table 1).

Observations of both these glacier regimes are available only for one or two benchmark glaciers (Glacier 31) in northeastern Siberia (Ananicheva, 2006) and Kozelsky Glacier (data published in Fluctuations of Glaciers, vol. V, VI, VII),

Published by Copernicus Publications on behalf of the European Geosciences Union. 


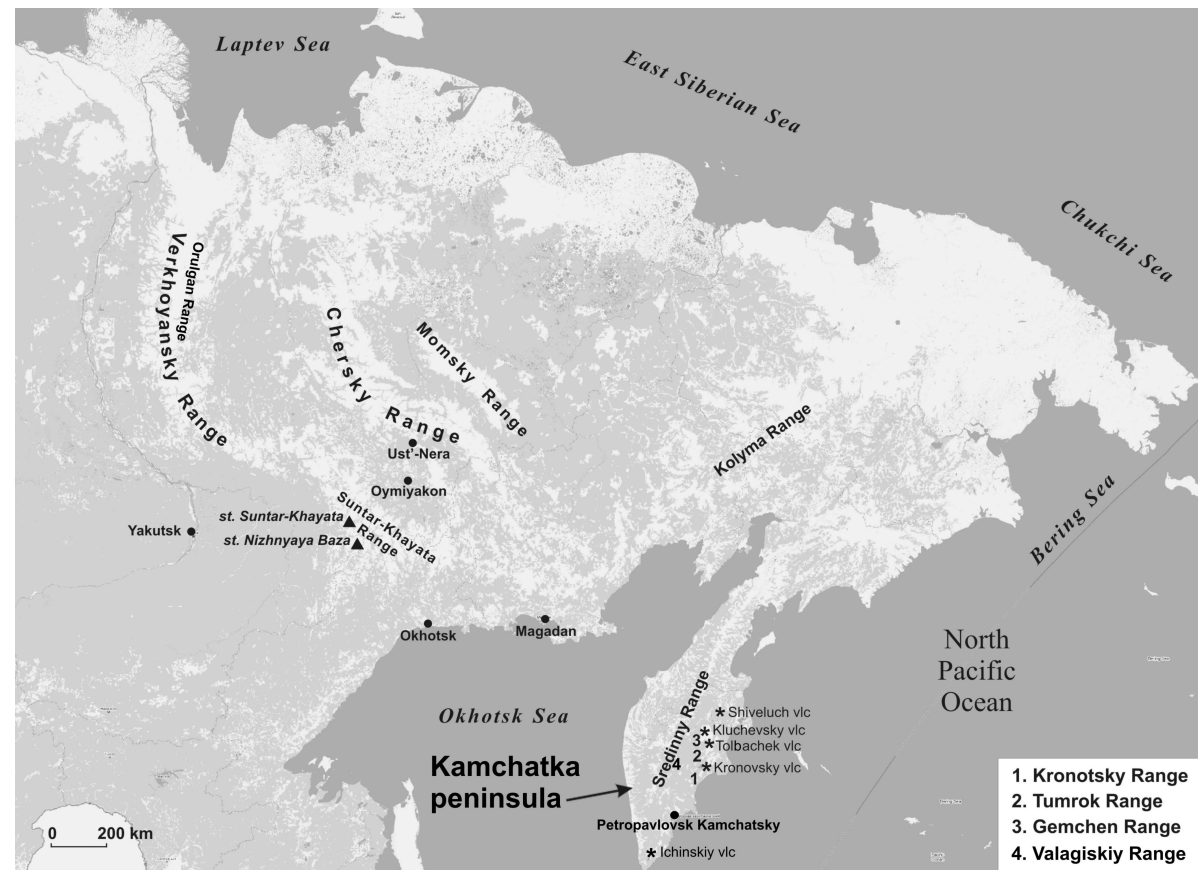

Fig. 1. Map of the study region.

so we used data from the USSR Glacier Inventory ${ }^{1}$ (19651982), also in the electronic glacier inventory in NSIDC, Boulder, $\mathrm{CO}$, which was based on aerial photography of the glaciers (Orulgan Range - in 1958, 1963; Suntar-Khayata Mountains - 1945, 1959, and 1970; Chersky Range - 1970s; Kamchatka - 1950).

Northeastern Siberia has undergone both winter and, to a lesser extent, summer warming since around 1960 until present, as well as the intensification of cyclone activity and precipitation (Ananicheva et al., 2003; IPCC, 2007). Due to these climatic trends, the proportion (and amount) of solid precipitation here has been increasing (Ananicheva and Krenke, 2005). Significant warming is also observed in Kamchatka (Shmakin and Popova, 2006).

\section{Glaciers studied}

Glacier regions (systems) analysed in this paper represent a wide spectrum of morphology and mass exchange types - from small cirque glaciers of the Orulgan range to large

\footnotetext{
${ }^{1}$ We used the following parts of the USSR Glacier Inventory: vol. 17 (Lena-Indigirka basins region), issue 2, part 2 (Orulgan), 1972, 43 pp.; issue 3, part 1, issue 5, part 2, issue 7, parts 2 and 3, 1981, 88 pp.; vol. 19 (North-East), part 3, 1981; vol. 20 (Kamchatka), parts 2-4, 1969, $74 \mathrm{pp}$.

The electronic version of the inventory is created in 1990s, it can be found at the NSIDC, Boulder, CO: Glacier Inventory - http: //nsidc.org/data/g01130.html
}

dendritic glaciers of the Chersky Range and specific volcanoglacier complexes of Kamchatka (Fig. 1).

\subsection{The Suntar-Khayata Range}

The Suntar-Khayata Range serves as a watershed between the river basins of the Aldan and the Indigirka tributaries entering the Arctic Ocean. Its elevations reach almost $3000 \mathrm{~m}$ a.s.l. It is one of the largest centers of present glacierization in northeastern Russia - about 195 glaciers cover $163 \mathrm{~km}^{2}$ (Ananicheva et al., 2006). The main source of snowfall for the glacier systems is moisture that has been brought from the Pacific and the Sea of Okhotsk, in particular in spring, summer and early autumn. For the northern glacier massif of the range, Arctic air invasions are also significant in winter which bring anticyclone weather.

\subsection{The Chersky Range mountain system}

The Chersky mountain system occupies the inner part of northeastern Siberia located to the north of the SuntarKhayata Range and closer to the Aleutian Low, in the area of prevailing moisture supply from the Pacific Ocean. Therefore, the overall ELA here is lower: $2150-2180 \mathrm{~m}$ against 2350-2400 m a.s.l. in the Suntar-Khayata Range. According to the latest assessments, the Chersky Range contains about 300 glaciers, which cover $113 \mathrm{~km}^{2}$, (Ananicheva et al., 2006). The Suntar-Khayata and Chersky mountains are located within $60^{\circ} \mathrm{N}-70^{\circ} \mathrm{N}, 138^{\circ} \mathrm{E}-150^{\circ} \mathrm{E}$. 


\subsection{Orulgan Ridge}

The glaciers of Orulgan Range (Verkoyansky Range) were first mapped in the 1940s. The present glacierization is located along the main watershed line, mainly on leeward (eastward-facing) slopes in concave relief forms - in two areas stretching $112 \mathrm{~km}$ and $25 \mathrm{~km}$ north to south. Glaciers of Orulgan (basically cirque and hanging glacier morphological types); about 80 glaciers covering $20 \mathrm{~km}^{2}$ exist on account of climate since the topography is relatively low. The modern glaciation is the only one in the continental-climateinfluenced part of Russia where glacier termini descend to $1500 \mathrm{~m}$; the ELA is lower than $2000 \mathrm{~m}$, and the glaciers face incoming cyclones from the North Atlantic and the western sector of the Arctic Ocean. The Orulgan Range glaciers massifs are located within $65^{\circ} \mathrm{N}-72^{\circ} \mathrm{N}, 128^{\circ} \mathrm{E}-131^{\circ} \mathrm{E}$.

\subsection{Kamchatka}

The Kamchatka glacierization consists of 448 glaciers, with a combined area of about $906 \mathrm{~km}^{2}$. Of these glaciers, $38 \%$ are located in the regions of active volcanism, and less than $19 \%$ in non-volcanic regions (Muraviev, 1999). Notably, out of all the glaciated regions considered, volcanism is the characteristic feature only for Kamchatka glaciers. The rest of glaciers cover the biggest, so called Sredinniy Range, stretching along the entire peninsula and a number of small mountain ranges, non-volcanic ones. The Kamchatka glaciers lie between 50 and $60^{\circ} \mathrm{N}$, near the Pacific Ocean and the Sea of Ohkotsk, which feed the glaciers with moisture from cyclones related mainly to the Aleutian Low.

Precipitation on the Kamchatka Peninsula is higher than over any other region of the Asian part of Russia and shows seasonal variations being under the influence of the monsoon (Muraviev, 1999). Precipitation increases from north-west ( $400 \mathrm{~mm} / \mathrm{yr}^{-1}$ ) to south-east (up to $2000 \mathrm{~mm} / \mathrm{yr}^{-1}$ ) according to lowland weather stations (Russian Hydrometeorological Service, http://www.meteo.ru).

The temperature and precipitation regimes, other climatic factors, relief and geological structures give rise to the modern maritime-type of glaciation. Due to abundant precipitation on Kronotsky Peninsula, facing the Pacific coast, the glaciers there descend to 250-500 ma.s.l. and the ELA is $\sim 1000 \mathrm{~m}$, whereas well inland on Kamchatka the ELA rises above $2200 \mathrm{~m}$ a.s.l. The Kamchatka mountain ranges and volcano peaks are located within $51^{\circ} \mathrm{N}-60^{\circ} \mathrm{N}, 156^{\circ} \mathrm{E}-$ $164^{\circ} \mathrm{E}$.

\section{Data and methods}

Our method for assessing the morphology and regime of glacier systems is based on changes of the mean ELA (which are defined by the intersection of accumulation and ablation 5 profiles, constructed by observed meteorological parameters) and the relation of the ELA and glacier termini elevation level under climate-change scenarios.

The method is consistent with both GCM and palaeoanalogue scenarios. We chose the ECHAM4/OPYC3GGa11, scenario, which predicts rather intensive warming by 2100 in comparison with other AOGCMs: thus we evaluate the maximum likely reduction of the glaciers. The model is a spectral one with 19 atmospheric layers, and the results used here derive from experiments performed with spatial resolution T42, which corresponds to about $2.8^{\circ}$ longitude/latitude resolution. The level of $\mathrm{CO}^{2}$ is $\sim 554 \mathrm{ppmv}$ (Bacher et al., 1998).

The choice is conditioned by our purpose of understanding how much the glacier systems of the Northeastern Asia, which are now under warming, would change if regional climate change either persists at the current rate or is somewhat enhanced. Current warming and retreat of glaciers in this vast region has become a motivation of the work presented. Also the choice was confirmed by the opinion of J. Walsh, V. M. Katsov and J. Overland (personal communication, 2009) that the ECHAM4 and then ECHAM5 climatic models outputs are optimal for the Northern Eurasia. However we have tested four key glacier systems by the scenarios of the other GCMs (see Sect. 6 of the paper). We considered 17 glacier regions (systems) from the two different climate and relief regions of Russian Asia: Northeastern Siberia (7 systems), and the Kamchatka Peninsula (10 systems), using climatic data from the second half of the 20th century (http://www.meteo.ru) and applying climatic scenarios. The vertical mass-balance (accumulation and ablation) profiles for these regions were constructed and became the basis for our projection of glacier evolution. The intersections of the vertical balance profiles give the values of the present-day and projected future ELA. The method of balance profile construction is described in Sects. 3.1 and 3.2. By using the USSR Glacier Inventory ${ }^{1}$ data for each system we constructed hypsographic schemes showing the distribution of ice-covered area versus altitude (Fig. 2: examples of hypsographic schemes for northeastern Asia). The ELA was assumed, when unknown, to be the arithmetic mean of the highest and lowest pointsof a glacier in the system. This assumption, based on the Gefer/Kurowski method (e.g. Hess, 1904; Kalesnik, 1963; Cogley, 2003), is used where glaciers are in balance with climate, which can reasonably be assumed to be the case for the USSR Glacier Inventory ${ }^{1}$ data (1950s to 1970s).

This assumption was verified using again the USSR Glacier Inventory ${ }^{1}$ for the Suntar-Khayata and Chersky mountain systems by comparison of these calculations with mean ELA values, derived by aerial photography for each glacier. The errors are as follows: Suntar-Khayata: Northern massif $-2.1 \%$, Southern Massif $-1.3 \%$, Chersky System: $5.2 \%$ (Buordakh Massif), 6.5\% (Terentyakh Massif), and $3.2 \%$ (Erikit Massif). The deviation error between values calculated by the Gefer/Kurowski method and those obtained 
Northern Massif of Suntar-Khayata
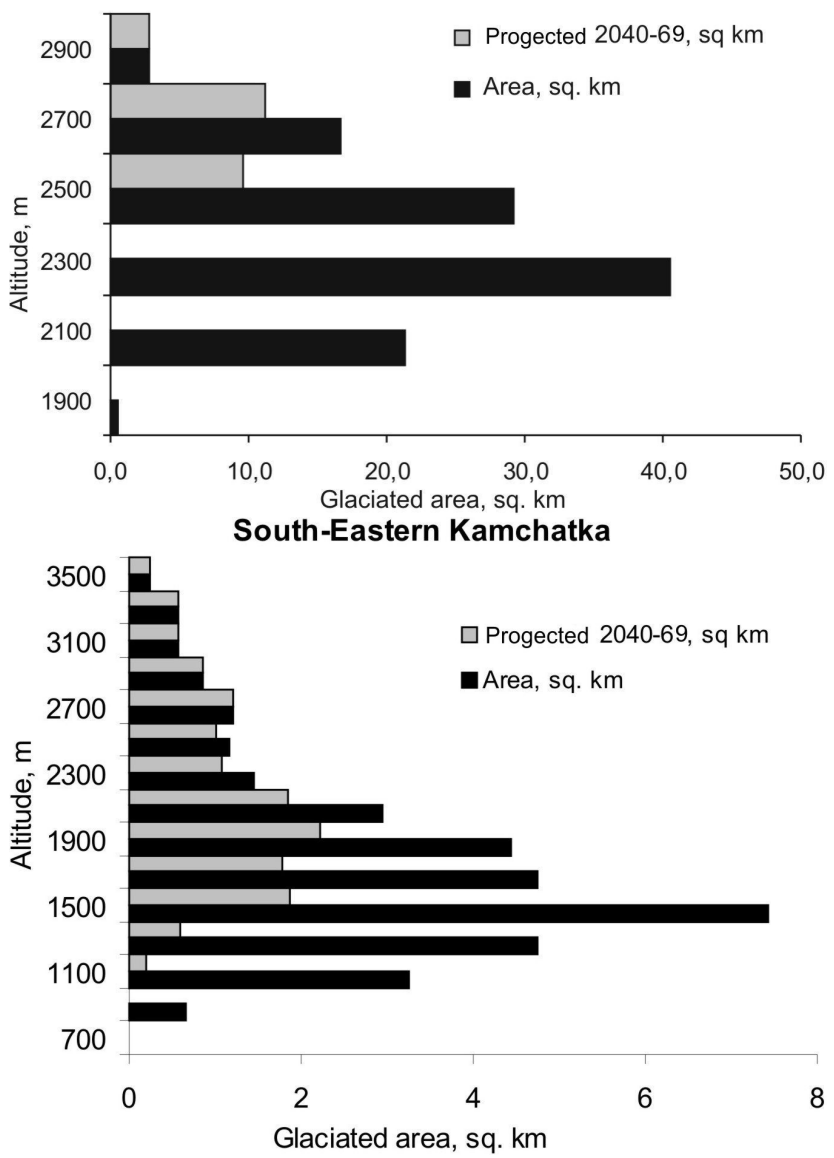

Fig. 2. Examples of hypsographic curves - distribution of ice area versus altitude for the northeast Siberia glaciers system (a), Kamchatka (b).

empirically, is therefore small. It is worth noting that Braithwaite and Raper (2007) found that the ELA and median glacier elevation are very strongly correlated across a wide range of glacier conditions. The area fraction of elevation intervals covered with ice is assumed, at this stage of the work, to decrease proportionally with altitude in regard to their distribution in the baseline period while a glacier is retreating. These elements constitute the essence of our new approach for assessing glacier-system change due to climatic fluctuations.

\subsection{Precipitation and temperature data}

The moisture supply conditions of the studied glacier systems vary widely from plentiful (monsoon type) in the eastern parts of Kamchatka (glaciers of the Kronotsky range) to least on the south-east of Orulgan. The Chersky and Suntar-Khayata ranges occupy an intermediate position in terms of glacier accumulation-ablation rate (Ananicheva and
Krenke, 2005). Comparison of data obtained between the late 1950s and 2001 about the glaciers of northeast Asia and their mass exchange, shows that they have undergone appreciable changes - as revealed through retreat of their termini, surface lowering, formation of new morainic deposits, etc.

By our estimates involving Landsat imagery of 2003, the Suntar-Khayata glaciers reduced their area since 1945 by $20 \%$ compared to 2003, those of Chersky Range retreated more - they lost as much as $28 \%$ of area since 1970 to 2003 (Anaicheva et al, 2006). The estimates of the Buoradkh Massif (a part of Chersky Range) glacier retreat by area was presented also in Gurney at al. (2008), the shrinkage of these glaciers was about $17 \%$ since the inventory started. These changes may largely be attributed to external factors since the high inertia of the given glaciers (due to their generally low energy of glacierization, low temperatures, and typical 200-400 m ice thickness; Koresha, 1991) do not encourage fast changes in their position and regime. As the temperature regime of the Suntar-Khayata region in the 20th century is suggested to be the dominant factor of the large changes in glacier size (Ananicheva et al., 2003), we analyzed long-term temperature and precipitation records for thirteen meteorological stations within $62-72^{\circ} \mathrm{N}$ and 121 $152^{\circ} \mathrm{E}$. The analysis of these series trends was carried out using the non-parametric Kendall-Mann-Sneyers test, with preliminary transformation of the series due to their extraordinary amplitude. We identified two phases of temperature fluctuations since the 1940s, with cooling and subsequent warming taking place up to now. For these phases the annual, winter and summer trends were calculated; for the warming phase their spatial distributions are shown in Fig. 3a-c.

In the Northeastern Siberia mountains during cooling periods, the greatest temperature decreases occurred in SON and MAM, exacerbating and prolonging winter cooling; however, warming phases were concentrated during JJA that enhanced ablation. The comparison of schematic distributions of seasonal temperature trends for the past $\sim 50$ years (19451995), and the signs of these values in particular, specify different "sources of intensification" for the DJF and JJA trends. The former increases from $\mathrm{N}$ to $\mathrm{S}$, the latter increases from NE to SW, (influence of the Sea of Okhotsk), and rapidly disappears towards the Arctic Ocean. In fact, in winter, warming is stronger within the continent (because of weakening of the Siberian high), and in summer it shifts toward Sea of Okhotsk. Trends of total precipitation until 1992 are slightly negative for the majority of stations, while solid precipitation only slightly increased since 1970s $(3-5 \mathrm{~mm}$ for 30 years) that is caused by warming (the Siberian High has been weakening). So, temperature change is likely to have been the dominant climatic forcing factor within most of the studied glacier systems during the last few decades. We may expect different reaction of the glacier systems to climate warming. According to the chosen climatic scenario the mean summer temperature would increase by between $3.1^{\circ}$ and $4.0^{\circ} \mathrm{C}$ throughout the study region by $2040-2069$, 


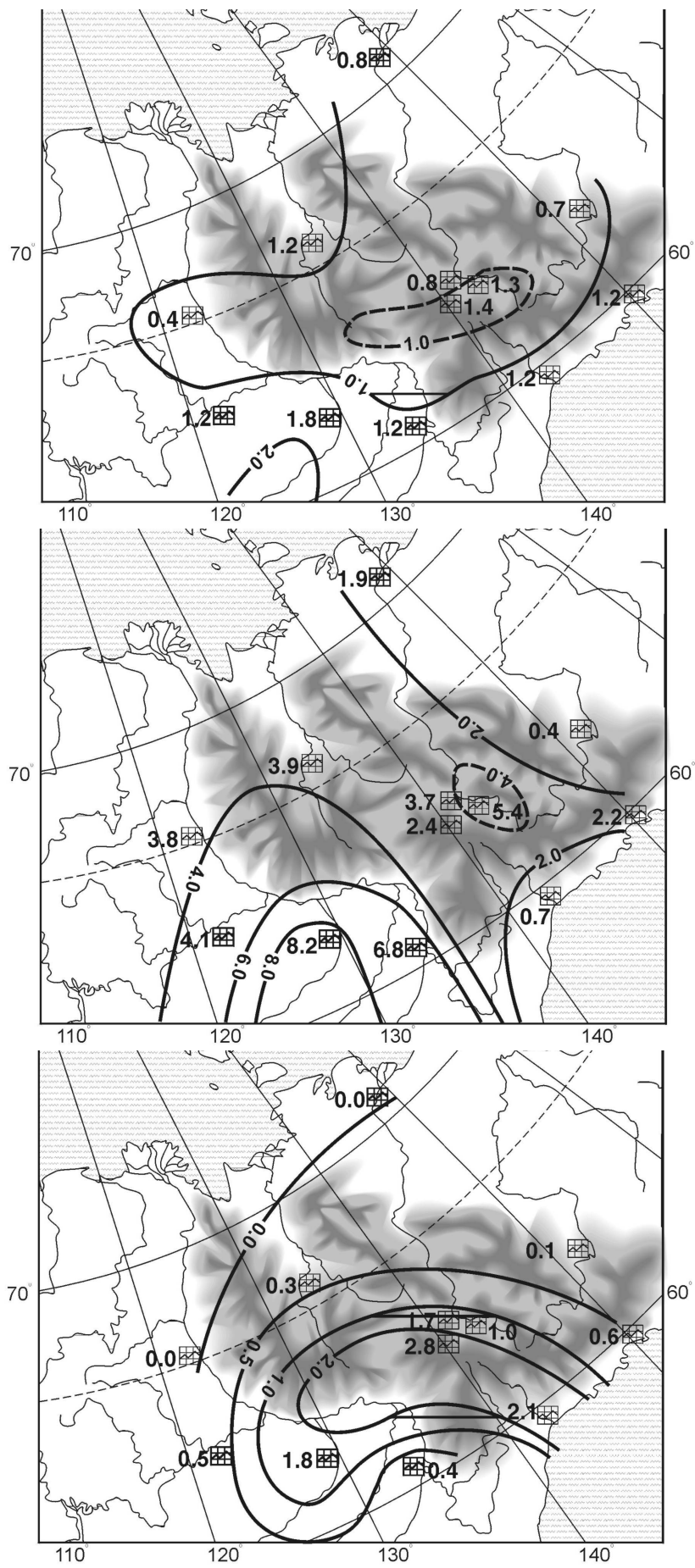

Fig. 3. Spatial distribution of positive temperature trends. (a) annual values for the warming up to $1995, T^{\circ} \mathrm{C} / 50$ years, (b) winter trends for the same period, $T^{\circ} \mathrm{C} / 50$ years, (c) summer trends for the same period, $T^{\circ} \mathrm{C} / 50$ years.

greatly exceeding the temperature difference between 30 year periods before and after the start of warming around 1960 (Ananicheva et al., 2002). The daily total precipitation given by this AOGCM was recalculated to solid precipitation in monthly amounts (for the accumulation on glaciers), using the Bogdanova method (Bogdanova, 1976; Bogdanova et al., 2002). It estimates the solid-precipitation fraction according to mean monthly temperature and elevation, taking account of the model baseline and increased (projected) temperatures. In northeastern Siberia under the ECHAM4 scenario, solid precipitation would tend to increase everywhere except the southern massif of Suntar-Khayata. The situation on Kamchatka is the opposite: solid precipitation would decline except in the south-east, where it might increase slightly.

To calculate the vertical distribution of present massbalance components we used all available climatic data, which mainly cover the second half of the twentieth century. This timeframe corresponds to the baseline (1960-1991) period used for reference in the ECHAM4 scenario of climate change for the next 80 years. Our baseline period approximately corresponds to the state of the glacierization reflected in the USSR Glacier Inventory ${ }^{1}$ and also partly covers the time preceding its compilation.

To complement the sparse meteorological-station data for high elevations (above $1000 \mathrm{~m}$ ), we used the accumulation at the mean ELA for the each glacier group (10-15 glaciers), which was calculated from the Glacier Inventory ${ }^{1}$ data or obtained from their maps (Krenke, 1982; Ananicheva and Krenke, 2005). These maps were widely used in the Atlas of Snow and Ice Resources, published in Moscow (Kotlyakov, 1997). At the ELA, accumulation $(C)$ is equal to ablation $(A)$, with the latter dependent on summer mean temperature (see Eq. 2 below). Among glacier regime characteristics related to high altitudes, $A$ is considered more reliable than $C$ because it is relatively easy to calculate it basing on air temperature, since temperature lapse rates are easier to define and therefore better known than precipitation lapse rates (e.g. Hanna and Valdes, 2001). Accumulation is then set equal to the ablation at the mean ELA. For each glacier system mentioned above, vertical profiles of $A$ and $C$ were constructed using the methods described below.

\subsection{Method: present accumulation/ablation calculation}

Accumulation was calculated based on solid precipitation measurements from weather stations; ablation by the relationship between it and mean summer air temperature. For the Northeastern Siberia, precipitation and temperature data were available only up to a height of $1400 \mathrm{~m}$ a.s.l. except for the high altitude (2068 ma.s.l.) station "Suntar-Khayata", which operated for 9 years (1957-1966) at the terminus of Glacier 31 in the northern massif of Suntar-Khayata Range. Based on this station's observations and data from an intermediate station at Nizhnya Baza $(1350 \mathrm{~m})$, located on the western slope of Suntar-Khayata Range, temperature lapse rates of $0.68^{\circ} \mathrm{C} / 100 \mathrm{~m}$ below $1000 \mathrm{~m}, 0.50^{\circ} \mathrm{C} / 100 \mathrm{~m}$ between $1000-1500 \mathrm{~m}$ and $0.60^{\circ} \mathrm{C} / 100 \mathrm{~m}$ above $1500 \mathrm{~m}$ were used for summer.

Weather stations on Kamchatka are situated within the altitude range of 100-400 ma.s.l. In situ meteorological 
observations in the Avachinskaya Volcano group (1963-1974 and 1975-1979) were made to a height of $1500 \mathrm{~m}$ a.s.l. The temperature lapse rate everywhere increases with altitude. However, inversions are not characteristic for this region, in contrast to northeast Siberia - in winter (Matsumoto et al., 1999). Based on these observations, we adopted lapse rates of $0.35^{\circ} \mathrm{C} / 100 \mathrm{~m}$ between 100 and $1000 \mathrm{~m}, 0.55^{\circ} \mathrm{C} / 100 \mathrm{~m}$ between 1000 and $2000 \mathrm{~m}$, and $0.60^{\circ} \mathrm{C} / 100 \mathrm{~m}$ above $2000 \mathrm{~m}$ (Vinogradov, 1975; Vinogradov and Martiaynov, 1980).

We extrapolated precipitation in northeast Siberia from the "Suntar-Khayata" station and in Kamchatka by precipitation gradients identified by observations at $1500 \mathrm{~m}$, incorporating corrections based on $C$ values at the ELA - with $C$, defined based on its equality to $A$ at this level. The next step was to construct a corresponding vertical A-profile for presentday climate (the baseline period). In northeast Siberia where glaciers are cold-based, superimposed ice prevails; therefore a significant fraction of meltwater refreezes and then melts again at the surface. In this case it is possible to use a regional variant of the "global" formula relating $A$ to summer temperature $\left(T_{\text {sum }}\right)$, presented by Krenke and Khodakov (1966; in Krenke, 1982), which was proposed by Koreisha (1991) and confirmed in calculations for Glacier 31 for reconstruction of the Suntar-Khayata glaciation during the Holocene optimum (Ananicheva and Davidovich, 2002):

$A=\left(T_{\text {sum }}+7\right)^{3}$

where $A$ is ablation in mm, and $T$ sum is the mean summer air temperature over glacier surface at the ELA in ${ }^{\circ} \mathrm{C}$.

This formula is obtained from the data of many glaciers. In Kamchatka, in maritime conditions we used a slightly modified variant of the formula (Krenke, 1982):

$A=1.33\left(T_{\text {sum }}+9.66\right)^{2.83}$

In both cases $T_{\text {sum }}$ over the glacier surface ( $T_{\mathrm{g}}$ ) was obtained according to the empiric formula:

$T_{\mathrm{g}}=0.85 T_{\mathrm{ng}}-1.2$,

where $T_{\text {ng }}$ is the temperature over the rocky (non-glacier) surface nearby the ELA of the a glacier, in ${ }^{\circ} \mathrm{C}$ (Davidovich and Ananicheva, 1996).

The calculation of accumulation profiles is made by a transformation using a coefficient of concentration $\left(K_{\mathrm{c}}\right)$. The solid precipitation contribution for each month, and then annually was defined, as explained above, by the Bogdanova method (Bogdanova, 1976; Bogdanova et al., 2002). It varies from zero in summer months, to $70-99 \%$ in winter, early spring and late autumn, to $10-20 \%$ in late spring and early autumn. Then, to take the account of the morphological type of a glacier in the glacier system, we introduced $K_{\mathrm{c}}$, which is responsible for snow redistribution, avalanche snow transfer, etc. onto glaciers, and snow blowing off volcano slopes (for Kamchatka glaciers). According to recommendations given by Krenke (1982), in the situation where cirque type glaciers
Kluychevskaya Volcano Group
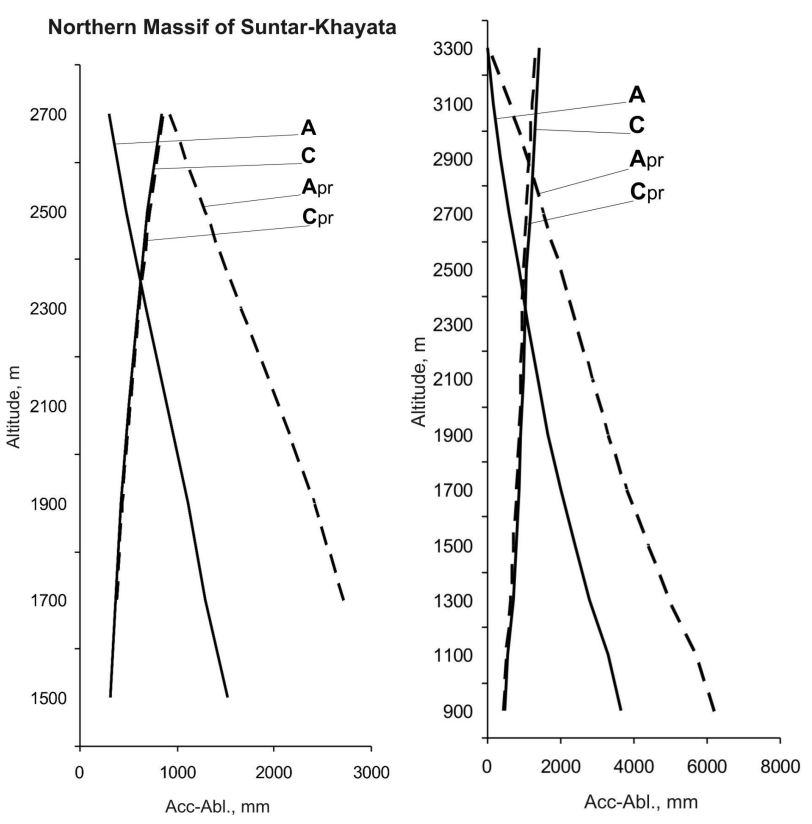

Fig. 4. Mass balance (accumulation and ablation, directed in oppositional way) vertical profiles for one glacier system of northeast Siberia - northern massif of Suntar-Khayata (a) and Kamchatka Kluychevskaya Volcano (b). Solid lines - baseline period, broken line - projection by ECHAM4, the keys at the profiles see in the text.

prevail (such as in the Orulgan, Valagisky, Tumrok and Gemchen ranges) $K_{\mathrm{c}}$ is assumed to be 1.6. For Chersky, SuntarKhayata, and Sredinny ranges, where medium-sized valley glaciers dominate, $K_{\mathrm{c}}$ is assumed to be 1.4. For volcanoes covered by ice caps on the cones in combination with large valley glaciers, we used a $K_{\mathrm{c}}$ of 1.4 until the cone end, and then $K_{\mathrm{c}}$ is reduced from 1.0 to $0.6-0.7$ on the slopes from which snow drifting prevailed.

For some glacier systems of Kamchatka we also used the mass-balance component profiles, obtained by Davidovich (2006) by the same approach. Examples of mass balance (accumulation and ablation) curves for both northeast Siberia and Kamchatka are given in Fig. 4.

\subsection{Method of projecting glacier change}

This section of the work involved the construction of projected ablation and accumulation curves, $A_{\mathrm{p}}$ and $C_{\mathrm{p}}$, for the climate of 2040-2069, based on $A$ and $C$ for the present time period. For ablation/accumulation we used the assumption that the temperature shift, presented in the scenario for each grid point, within which the given glacier system is located, spreads over the entire (real-surface) altitudinal range encompassed by a glacier system. 


\subsection{Calculation of projected accumulation/ablation}

For all glacier systems considered, the mean summer temperature increase from current conditions is projected to lie within the range $3.1^{\circ}-4.0^{\circ} \mathrm{C}$. Projected summer temperature values were incorporated in the calculation of $A$ described above. We used the temperature increase at the icerock boundary due to microclimatic influences and the melt process - glacier surfaces depress air temperature compared with non-glacier surfaces and so experience a reduced warming rate.

We used projected daily precipitation to calculate monthly solid precipitationboth for the baseline and for 2049-2060 using the Bogdanova $(1976,2002)$ method and the projected temperatures. The purpose was to obtain ratio coefficients of solid precipitation for the projected time interval compared with present for all glacier systems. Note that in northeastern Siberia, under the significant warmingof the given scenario, solid precipitation is predicted to increase everywhere (coefficients are from 1.09 to 1.46) except for the southern massif of Suntar-Khayata (0.99).

In Kamchatka the situation is the opposite: solid precipitation will decrease slightly $(0.74-0.96)$ except for the southeast where it rises slightly (1.08). Thus the southern parts of the region under consideration will be so warm that the solid precipitation will decrease due to the longer time period with positive temperatures.

In using these coefficients in the calculation of accumulation for the projected period, we assumed that this ratio did not change with altitude. As a result we obtained vertical curves of $C_{\mathrm{p}}$ for all glacier systems in 2040-2069.

The intersections with the scenario-based curves $A_{\mathrm{p}}$ are taken to obtain the mean ELA for 2040-2069 for the glacier system - ELAp. Its shift is rarely higher than the highest point of the area of accumulation $\left(H_{\text {high }}\right)$ in the system (a scenario, which would mean that the glacier ice should disappear).

\subsection{The projection of the glacier terminus altitude level change}

In other cases it is assumed that after adaptation of the glacier to the new climate in accordance with the Gefer/Kurowski method of ELA identification (ELA is the arithmetic mean of the highest and the lowest glacier points; Kalesnik, 1963), the elevation difference between the top of the glacier $H$ high and ELAp is equal to the elevation difference between ELA $A_{p}$ and glacier terminus $\left(H_{\text {ends }}\right)$. Under the assumption that the same is valid for whole glacier system, we derive the following formula for the altitude of the lowest glacier height position:

$H_{\text {ends }}=\mathrm{ELA}_{\mathrm{p}}-H_{\text {high }}-\mathrm{ELA}_{\mathrm{p}}=2 \mathrm{ELA}_{\mathrm{p}}-H_{\text {high }}$

Using this simple equation, we obtained the projected distributions of ice against altitude for the glacier systems under consideration for the period 2040-2069. Their lowest point coincides with $H_{\text {ends }}$, where the glacierzed area equals zero, and the highest point remains unchanged. The correlation change of the ELA is thus related to the glacier-terminus level by this relationship.

The ice distribution at intermediate elevation steps changes in proportion to altitude from zero (at $H_{\text {high }}$ ) to $100 \%$ preservation (at $H_{\text {ends }}$ ) relative to the baseline period (see the hypsographic scheme of ice distribution vs. altitude, example in Fig. 2). This is a "linear" hypothesis assumption.

Projected ice areas for the glacier systems were multiplied by $A_{\mathrm{p}}$ and $C_{\mathrm{p}}$ to derive the distribution of projected ablation/accumulation volumes versus altitude for the climatic conditions of the scenario (2049-2060). See Fig. 4, where projected balance profiles are indicated by the broken line. The comparison of the projected profiles of mass-balance components with the highest and lowest elevations of the glaciers derived from the USSR Inventory ${ }^{1}$ data (1940-1970) also enables us to estimate the change of the ratio of glacier morphology types and related parameters - not just glacier balance and area - under climate change scenarios.

\section{Results of the "linear" assumption of future ice distribution via altitude and discussion}

Using the ECHAM4 scenario described above, we obtained the following projected estimations of the ELA change. The shift upward of the ELA, $\Delta H_{\text {ela }}$, as a result of warming and glacier retreat is less in the northern parts of northeast Siberia than in the south $(230 \mathrm{~m}$ as against $500 \mathrm{~m}$ in the south). In Kamchatka $\Delta H_{\text {ela }}$ as a rule is more significant depending on precipitation rate. The largest $\Delta H_{\text {ela }}$ (up to $1210 \mathrm{~m}$ ) was found in the south of IchinskiyVolcano, located in the "rain shadow" of the Sredinniy Range (Table 1).

The change in glacierized area is anticipated to range from a complete disappearance of some minor glacier systems, to the preservation of $70 \%$ of the present area (Kluchevskaya volcano group) and 50\% of the contemporary ice area (Shiveluch and Tolbachek volcanoes). Under the warming scenario, as calculated by our approach, glaciers will not be present in the southern systems of northeast Siberia - the southern regions of Orulgan glaciers and the Suntar-Khayata Mountains, small mountain ranges of Kamchatka around Ichinskiy Volcano.

Those glaciers covering the volcanoes of southeastern Kamchatka and receiving intensive moisture supply due to the elevation of the peaks and proximity of the Pacific Ocean would preserve more than $40 \%$ of their area.

As for the intensity of mass exchange at the ELA, we can expect the following changes in ablation and accumulation during the projected period compared with the baseline period. $\triangle A$ and $C$ at the ELA is greater for NE Siberia on the north of the Orulgan, Chersky, and Suntar-Khayata ranges, where precipitation due to warming will increase from 200 to almost $500 \mathrm{~mm}$. Orulgan derives moisture from the North 
Table 1. Change of glacier systems characteristics in Northeastern Siberia and Kamchatka up to the mid 21st century (2040-2069).

\begin{tabular}{|c|c|c|c|c|c|c|c|c|c|}
\hline \multirow[t]{2}{*}{ Glacier system } & \multirow{2}{*}{$\begin{array}{c}\text { The shift of } \\
\Delta H_{\text {ela }} \\
\text { (from basic to } \\
\text { projected } \\
\text { period), } \\
\text { m }\end{array}$} & \multicolumn{2}{|c|}{$\begin{array}{c}\text { The elevation range } \\
\text { of the glacier system , } \\
\mathrm{m}\end{array}$} & \multicolumn{2}{|c|}{$\begin{array}{c}\text { Glaciated area, } \\
\mathrm{km}^{2}, \%\end{array}$} & \multicolumn{2}{|c|}{$\begin{array}{c}\text { Ablation and } \\
\text { accumulation at the } \\
H_{\text {ela }}, \mathrm{mm}\end{array}$} & \multicolumn{2}{|c|}{ Balance, $\mathrm{cm} \mathrm{yr}^{-1}$} \\
\hline & & $\begin{array}{l}\text { Basic } \\
\text { period }\end{array}$ & $\begin{array}{l}\text { Projected } \\
\text { period }\end{array}$ & $\begin{array}{c}\text { Basic period, } \\
\mathrm{km}^{2}\end{array}$ & $\begin{array}{l}\text { Projected period, } \\
\mathrm{km}^{2}(\%)\end{array}$ & $\begin{array}{l}\text { Basic } \\
\text { period }\end{array}$ & $\begin{array}{l}\text { Projected } \\
\text { period }\end{array}$ & $\begin{array}{l}\text { Basic } \\
\text { period }\end{array}$ & $\begin{array}{c}\text { Projected } \\
\text { period }\end{array}$ \\
\hline \multicolumn{10}{|c|}{ Northeastern Siberia } \\
\hline Orulgan Northern Knot & 250 & 750 & 400 & 7 & $2(27)$ & 740 & 1230 & +23 & 0 \\
\hline Orulgan Southern Knot & 500 & 760 & 0 & 12 & 0 & 580 & 0 & +14 & - \\
\hline Cherskiy-Erikit knot & 320 & 700 & 200 & 7 & $1(10)$ & 710 & 1020 & +7 & 0 \\
\hline Cherskiy-Buordakh & 300 & 1640 & 1280 & 63 & $18(29)$ & 700 & 1050 & -2 & -11 \\
\hline Cerskiy-Terentykh & 300 & 1520 & 1180 & 28 & $8(29)$ & 720 & 1130 & +2 & +6 \\
\hline Suntar-Khayata, North & 350 & 1080 & 520 & 111 & $26(23)$ & 620 & 850 & -26 & -70 \\
\hline Suntar-Khayata, South & 500 & 1110 & 60 & 22 & $0.4(2)$ & 460 & 650 & -40 & -30 \\
\hline SUM & & & & 250 & $55.4(22)$ & & & & \\
\hline \multicolumn{10}{|c|}{ Kamchatka } \\
\hline $\begin{array}{l}\text { Sredinny Range } \\
\text { Eastern Slope }\end{array}$ & 600 & 2850 & 2160 & 124 & $24(20)$ & 1430 & 1460 & -44 & -170 \\
\hline $\begin{array}{l}\text { Sredinny Range } \\
\text { Western Slope }\end{array}$ & 570 & 1900 & 1330 & 264 & $55(21)$ & 1430 & 1470 & +20 & -44 \\
\hline Shiveluch Volcano & 600 & 3240 & 2720 & 30 & $16(52)$ & 1160 & 1080 & -36 & -50 \\
\hline Kluchevskaya Group & 420 & 3950 & 3660 & 124 & $85(69)$ & 1000 & 1100 & +31 & -4 \\
\hline Tolbachek Volcano & 580 & 3085 & 2680 & 70 & $33(47)$ & 1200 & 1350 & +50 & +3 \\
\hline $\begin{array}{l}\text { Tumrok and Gemchen } \\
\text { ranges }\end{array}$ & 430 & 1020 & 0 & 11 & 0 & 1710 & 0 & -81 & - \\
\hline Khronotskiy Range & 510 & 1150 & 260 & 91 & $9(10)$ & 3350 & 3800 & -48 & -116 \\
\hline Valaginskiy Range & 610 & 1000 & 0 & 9 & 0 & 1400 & 0 & -40 & - \\
\hline $\begin{array}{l}\text { Volcanows of South- } \\
\text { Eastern Kamchatka }\end{array}$ & 300 & 2660 & 2340 & 34 & $14(41)$ & 1350 & 1550 & -44 & -60 \\
\hline Ichinskiy Volcano & 740 & 2080 & 780 & 29 & $6(22)$ & 1510 & 1550 & +17 & +3 \\
\hline SUM & & & & 786 & $242(30.8)$ & & & & \\
\hline SUM totally & & & & 1036 & & & & & \\
\hline $\begin{array}{l}\text { Ichinskiy Volcano (with } \\
\text { account of blow-off from } \\
\text { the slopes) }\end{array}$ & $1210^{*}$ & 2080 & 0 & 29 & 0 & 1510 & $800 *$ & +17 & - \\
\hline
\end{tabular}

* The projected elevations are higher than the real topography, so the glaciarization in these cases will not exist under the scenario used.

Atlantic; Chersky - from both Atlantic and Pacific, while Suntar-Khayata mountains also receive moisture from the Pacific Ocean. In glacier systems of Kamchatka only the Kronotsky Range and volcanoes of the south-eastern part of the peninsula are characterized by high increase of $A, C$ : $\triangle A, C$ from 200 to $450 \mathrm{~mm}$ at the ELA; these are areas of plentiful precipitation, and despite the solid precipitation portion reducing during warming, it would still be a large absolute value. In the rest of the Kamchatka systems $\Delta A, C$ will range from 30 to $150 \mathrm{~mm}$ as a result of reduced snow accumulation because of strong warming.

The glaciers of the Shiveluch Volcano attain negative $\Delta A$ , $C$-values at the ELA (decrease of these parameters) due to the rather abrupt decrease of the solid-precipitation fraction. Judging from the Glacier balance averages both for the baseline and projected periods, the glacier systems have different sensitivities to current climatic conditions and predicted future climate change. Under a constant climate, when glacier mass balance is close to zero, the glacier will not change; but assuming the same constant climate, if mass balance is positive, the glacier will expand, while if it is negative it will shrink. The balance trend, stability or change, and its sign are controlled by climatic conditions. A glacier can "keep up" with climate change - in this case its balance also remains near zero as well as consistent with climate. Among the glacier conditions considered, only that of the Chersky Range has been in this state during the baseline period. Glaciers of the Orulgan, the western slope of Sredinniy Range, the Kluchevskya Volcano group and Tolbachek in Kamchatka were growing at that time. The rest have retreated. 
Table 2. Change of the main glacier system characteristics for a "non-linear" distribution of ice versus altitude under climate warming: ECHAM4 - scenario, 2040-2069.

\begin{tabular}{|c|c|c|c|c|c|c|c|c|c|c|c|c|}
\hline \multirow{2}{*}{$\begin{array}{l}\text { The } \\
\text { location } \\
\text { of the } \\
\text { glacier } \\
\text { system }\end{array}$} & \multirow[t]{2}{*}{ Base } & \multicolumn{2}{|c|}{$\begin{array}{l}\text { The elevation } \\
\text { distribution of the } \\
\text { system, } m\end{array}$} & \multirow[t]{2}{*}{ Base } & \multicolumn{2}{|c|}{$\begin{array}{c}\text { The area of } \\
\text { glacierization, } \\
\mathrm{km}^{2}\end{array}$} & \multirow[t]{2}{*}{ Base } & \multicolumn{2}{|c|}{$\begin{array}{l}\text { Ablation- } \\
\text { accumulation at the } \\
\text { ELA, mm }\end{array}$} & \multirow[t]{2}{*}{ Basic } & \multicolumn{2}{|c|}{ Balance, $\mathrm{cm} /$ year } \\
\hline & & $\begin{array}{c}\text { ECHAM4 } \\
\text { Linear }\end{array}$ & $\begin{array}{l}\text { ECHAM4 } \\
\text { Non- } \\
\text { linear }\end{array}$ & & $\begin{array}{c}\text { ECHAM4 } \\
\text { Linear }\end{array}$ & $\begin{array}{l}\text { ECHAM4 } \\
\text { Non- } \\
\text { linear }\end{array}$ & & $\begin{array}{c}\text { ECHAM4 } \\
\text { Linear }\end{array}$ & $\begin{array}{l}\text { ECHAM4 } \\
\text { Non- } \\
\text { linear }\end{array}$ & & $\begin{array}{c}\text { ECHAM4 } \\
\text { Linear }\end{array}$ & $\begin{array}{l}\text { ECHAM4 } \\
\text { Non- } \\
\text { linear }\end{array}$ \\
\hline $\begin{array}{l}\text { Chersky- } \\
\text { Buordakh }\end{array}$ & 1640 & 1288 & 1000 & 63 & 18 & 28.4 & 700 & 1050 & 1050 & -2 & $-22,8$ & -0.05 \\
\hline $\begin{array}{l}\text { Suntar- } \\
\text { Khayata, } \\
\text { North }\end{array}$ & 1110 & 520 & 700 & 111 & 9 & 21.6 & 460 & 850 & 850 & -40 & -70 & -59.1 \\
\hline $\begin{array}{l}\text { Kronotsky } \\
\text { Range }\end{array}$ & 1150 & 260 & 300 & 91 & 26 & 1.04 & 3350 & 3800 & 3800 & -48 & -116 & -4.8 \\
\hline $\begin{array}{l}\text { Ichinsky } \\
\text { Volcano }\end{array}$ & 2080 & 780 & 600 & 29.3 & 6 & 6.68 & 1510 & 1550 & 1550 & +17 & +3 & 124.1 \\
\hline
\end{tabular}

For the 2040-2069 period, the northern region of Orulgan glaciers and glaciers of the Kluchevskya and Tolbachek volcanoes are predicted to come into equilibrium with climate. Despite the intensive warming scenario, the Chersky glaciers will still be consistent with climate: this is due to a combination of elevation, relief forms and corresponding glacier morphology and regime, leading to their quite slow movement and change. Glaciers of the Sredinniy and Kronotsky ranges, Shiveluch and Southeastern

Kamchatka volcanoes will undergo accelerated retreat and provide evidence of a time lag when compared with the warming rate.

Verification of the results was done by comparing the calculation of projected parameters (ELA, glacier termius level and glacier areas) for the period from the 1957 International Geophysical Year (IGY) until the modeled period 2010-2039 with data of actual glacier changes obtained based on Landsat satellite imagery (Ananicheva at al., 2006), already mentioned above. The tendency of the glaciated area loss rate (20\% for $\sim 50$ years for Suntar-Khayata 10 and 30\% for 30 years for Chersky Range) seems be consistent with our projection results according to the rate of climate warming within the ECHAM4 scenario, if we keep in mind that the projected time slice is 2049-2060.

\section{5 "Non-linear" hypothesis of ice-distribution versus altitude under climate warming}

Besides the "linear" hypothesis of the decrease of glacierization vs. altitude, for four key glacier systems we also applied a non-linear distribution of ice under warming throughout each of four glaciers systems. For this we obtained an

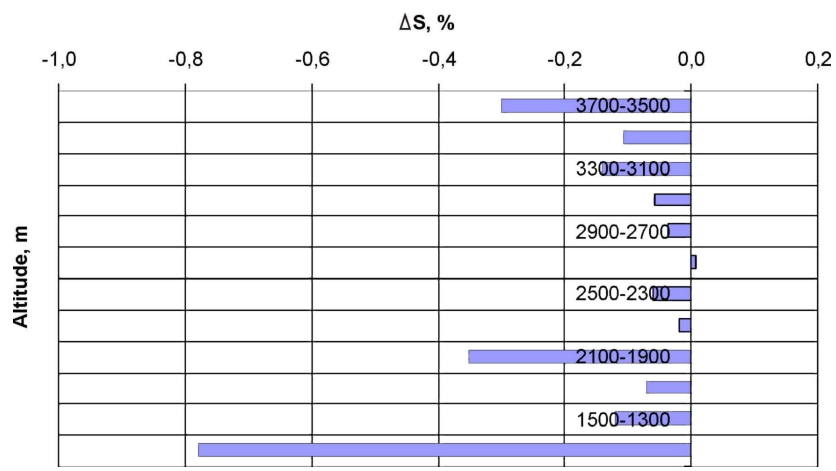

Fig. 5. The empirical curve of the ice distribution versus altitude as the difference between 30-year surveys for four glaciers (two Alpine and two Scandinavian).

empirical curve of the ice area zones by altitude as the difference between 30-year surveys for four glaciers (two Alpine and two Scandinavian, all are of valley morphological type, prevailing for the key glacier regions), see Fig. 5.

We used data of recurrent elevation surveys from "Fluctuations of glaciers", published by the World Glacier Monitoring Service in Zurich (http://www.geo.uzh.ch/wgms/fog. $\mathrm{html}$ ). We recalculated the distribution of areas covered with ice for the projected period with respect to this empirical curve. According to it the "new" area distribution with altitude will undergo less change than by the "linear hypothesis": the shrinkage in upper zones will be compensated with less area decrease in the central part of the glacier system. The mass balance correspondingly will be larger under a nonlinear distribution, but mostly negative. 
Table 3. The change of the main characteristics for key glacier systems by three GCMs to 2040-2069. Non-linear distribution of ice via altitude while glacier retreating.

\begin{tabular}{|c|c|c|c|c|c|c|c|c|c|c|c|c|c|c|c|c|}
\hline \multirow{2}{*}{$\begin{array}{l}\text { The } \\
\text { location } \\
\text { of the } \\
\text { glacier } \\
\text { system }\end{array}$} & \multirow[t]{2}{*}{$\begin{array}{l}\text { Base } \\
\text { line }\end{array}$} & \multicolumn{3}{|c|}{$\begin{array}{c}\text { The elevation } \\
\text { distribution of the } \\
\text { system, } m\end{array}$} & \multirow[t]{2}{*}{$\begin{array}{l}\text { Base } \\
\text { line }\end{array}$} & \multicolumn{3}{|c|}{$\begin{array}{l}\text { The area of the glacier } \\
\text { system glacierization, } \\
\mathrm{km}^{2}\end{array}$} & \multirow[t]{2}{*}{$\begin{array}{l}\text { Base } \\
\text { line }\end{array}$} & \multicolumn{3}{|c|}{$\begin{array}{l}\text { Ablation-accumulation } \\
\text { the ELA, mm }\end{array}$} & \multirow[t]{2}{*}{$\begin{array}{l}\text { Base } \\
\text { line }\end{array}$} & \multicolumn{3}{|c|}{ Balance, $\mathrm{cm} /$ year } \\
\hline & & ECHAM4 & Hadley & Japan & & ECHAM4 & Hadley & Japan & & ECHAM4 & Hadley & Japan & & ECHAM4 & Hadley & Japan \\
\hline $\begin{array}{l}\text { Chersky- } \\
\text { Buordakh }\end{array}$ & 1640 & 1000 & 1600 & 400 & 63 & 28.4 & 53.4 & 4.02 & 700 & 1050 & 660 & 1100 & -2 & -22.8 & 4.3 & 34.8 \\
\hline $\begin{array}{l}\text { Suntar- } \\
\text { Khayata, } \\
\text { North }\end{array}$ & 1110 & 700 & 1100 & 300 & 111 & 26.0 & 63.4 & 2.4 & 460 & 850 & 600 & 1200 & -40 & -59.1 & -49.7 & -150 \\
\hline $\begin{array}{l}\text { Kronotsky } \\
\text { Range }\end{array}$ & 1150 & 300 & 1000 & 300 & 91 & 1.04 & 80.4 & 0.57 & 3350 & 3350 & 3600 & 3300 & -48 & -4.8 & -10 & -21.1 \\
\hline $\begin{array}{l}\text { Ichinsky } \\
\text { Volcano }\end{array}$ & 2080 & 600 & 2080 & 1400 & 29.3 & 6.68 & 29.3 & 21.12 & 1510 & 1550 & 1470 & 1500 & 17 & 124.1 & 26.8 & -30.9 \\
\hline
\end{tabular}

Thus, under the ECHAM4 scenario the glacierization of the studied regions will not come into equilibrium with climate and will keep decreasing.

For 2040-2069 under a non-linear distribution of ice under warming, the elevation distribution 5 of glaciers will shrink by $40 \%$ in northeast Siberia and 3-4 fold in Kamchatka. The glacierized area will decrease twofold on the Chersky Range, five times in Suntar-Khayata, and as much as in 80 times on Kronotsky volcano, it will be at the threshold of vanishing (Table 2).

\section{Results of the application of Hadley and Japan model scenarios}

We also tested four mentioned key glacier systems by applying the outputs of the Had CM2GSDX (minimal warming) and the Japanese Model - CCSRGSA1 (JJGSA), maximal warming (see Table 3). Under the minor warming of the HadCM2 scenario (Cullen, 1993) the elevation distribution of glaciers will be almost the same as now. The glacier area, which covers Ichinsky Volcano will not change, the rest will lose 10-35\%. The accumulation-ablation at the ELA will show minor change, decreasing by 10-20\%. In the SuntarKhayata and on Kronotsky Range, despite a high moisture supply, the mass balance will remain negative; that means the glacierization will not come into balance with climate and will persistently decline. In Buordakh (Chersky) and on Ichinskiy Volcano under climate stabilization, the glaciers will persist.

The Japanese scenario CCSRGSA1 (JJGSA) (Nakajima and Tanaka, 1986) presents the most intensive warming for the regions mentioned. The elevation distribution of the glaciers in all systems (except Ichisky Volcano) will decrease 4-5 fold. In Ichinsky the shrinkage is only $25 \%$; the volcano cone will remain under ice cover (due to its large area) and only small glaciers will disappear. Correspondingly, the area of glaciers of the Ichinsky Volcano will shrink to $22.1 \mathrm{~km}^{2}$.The slope and cirque glaciers will remain unchanged. In Chersky and Suntar-Khayata under this scenario the accumulation-ablation will increase because of snow accumulation. It will stay high on Kronotsky Range. The glaciers of all key regions will have negative mass balance and therefore disappear soon after 2070, in response to the high warming rate.

\section{Conclusions}

A new approach involving calculating the average ELA and glacier-termini level for present and projected future climate states has been used to assess glacier-system change due to predicted climate change. We have used this approach to study glacier systems with a wide spectrum of morphology and regime types from small cirque glaciers of the Orulgan range to large dendritic glaciers of the Chersky Range, and specific volcano-glacier complexes of Kamchatka. The conditions of glacier nourishment vary widely and the reaction of these glacier systems to climate warming is found to vary considerably.

Calculation of projected changes predict that the upward shift of ELA, is less in the northern parts of the Northeast Siberia ( $230 \mathrm{~m}$ as against $500 \mathrm{~m}$ in the south), while in Kamchatka this shift is greater as a rule and depends on precipitation rate. Our calculations also predict the disappearance of some glacier systems, while others will preserve $70 \%$ of their present area.

Our simple climate-based approach allows the evaluation of the behavior of mountain glacier systems under specified climatic scenarios for any glacierized mountains worldwide and can serven as a tool for glacier morphology and regime forecasts for the medium-term future. The originality of our approach consists in the definition of glacier-climate characteristics for a glacier system, and we have applied this here 
for the first time to a projection of glacier-system change. By so doing, we have derived important information about the climate sensitivity of glaciers in Northeast Siberia and Kamchatka Peninsula.

The future development of the glacier systems are defined by scenario choice and assumptions. The glacierization of Northeast Siberia and Kamchatka will be considerably reduced under the ECHAM4 scenario: under a "linear" ice distribution with altitude more than under a "non-linear" distribution.

Acknowledgements. We are grateful to E. Hanna who contributed to the paper with valuable notes. We also are very grateful to the reviewers for their great job in checking our paper ant to the editor S. Marshall.

Edited by: S. Marshall

\section{References}

Ananicheva, M. D., Davidovich, N. V., and Mercier, J.-L.: Climate change in North-East of Siberia in the last hundred years and recession of Suntar-Khayata glaciers, Data of glaciologic studies, Moscow, 94, 216-225, 2003.

Ananicheva, M. D. and Davidovich, N. V.: Reconstruction of the Suntar-Khayata glaciation's in the periods of Quaternary climatic optima, Data Glaciol. Stud., 93, 73-79, 2002.

Ananicheva, M. D. and Krenke, A. N.: Evolution of Climatic Snow Line and Equilibrium Line Altitudes- North-Eastern Siberia Mountains in the 20th Century - Ice and Climate News, WCRP Climate and Cryosphere Newsletter, N 6, 1-6 July, 2005.

Ananicheva, M. D.: Suntar-Khayata and Chersky ranges in the Chapter "Glaciation fluctuations", in: Glaciation in North and Central Eurasia in the Recent at present time, edited by: Kotlyakov, V. M.. Moscow, Nauka, 198-204, 2006.

Ananicheva, M. D., Kapustin, G. A., and Koreysha, M. M.: Glacier changes in Suntar-Khayata mountains and Chersky Range from the Glacier Inventory of the USSR and satellite images 20012003, Data Glaciol. Stud., Moscow, 101, 163-169, 2006.

Bacher, A., Oberhuber, J. M., and Roeckner, E.: ENSO dynamics and seasonal cycle in the tropical Pacific as simulated by the ECHAM4/OPYC3 coupled general circulation model, Clim. Dynam., 14, 431-450, 1998.

Bogdanova, A. G.: Method of for calculation of solid and mixed precipitation proportion in their monthly standard, Data Glaciol. Stud., 26, 202-207, 1976.

Bogdanova, E. G., Ilyin, B. M., and Dragomilova, I. V.: Application of a comprehensive bias correction model to precipitation measured at Russian North Pole drifting stations, J. Hydrometeorol., 3, 700-713, 2002.

Braithwaite, R. J. and Raper, S. C. B.: Glaciological conditions in seven contrasting regions estimated with the degree-day model, Ann. Glaciol., 46, 297-302, 2007.

Chinn, T. J., Heydenrych, C., and Salinger, M. J.: Use of the ELA as a practical method of monitoring glacier response to climate in New Zealand's Southern Alps, J. Glaciol., 172, 85-95, 2005.

Cogley, J. G. and McIntyre, M. S.: Hess Altitudes and Other Morphological Estimators of Glacier Equilibrium. Arctic, Antarctic, and Alpine Research., 35(4), 482-488, 2003.
Cullen, M. J. P.: The Unified Forecast/Climate Model, Meteorol. Mag., 122, 81-94, 1993.

Davidovich, N. V.: Kamchatka glaciation during the Holocene Optimum (2006), Data Glaciol. Stud., 101, 221-229, 2006.

Davidovich, N. V. and Ananicheva, M. D.: Prediction of possible changes in glacio-hydrological characteristics under global warming: south-eastern Alaska, USA, J. Glaciol., 42, 407-412, 1996.

Dowdeswell, J. A. and Hagen, J. O.: Arctic ice caps and glaciers, in: Mass Balance of the Cryosphere: Observations and Modelling of Contemporary and Future Changes, edited by: Bamber, J. L. and Payne, A. J., Cambridge University Press, 527-557, 2004.

Gurney, S. D., Popovnin, V. V., Shahgedanova, M., and Stokes, C. R.: A Glacier Inventory for the Buordakh Massif, Cherskiy Range, North East Siberia, and Evidence for Recent Glacier Recession, Arct. Antarct. Alp. Res., 40(1), 81-88, 2008.

Hanna, E. and Valdes, P.: Validation of ECMWF (re)analysis surface climate data, 1979-98 for Greenland and implications for mass balance modeling of the Ice Sheet, Int. J. Climatol., 21, 171-195, 2001.

Hess, H.: Die Gletscher, Braunshweig, F. Vieweg u. Sohn, 426 pp., 1904.

IPCC, the 4th assessment, Contribution of Working Group I to the Fourth Assessment Report of the Intergovernmental Panel on Climate Change, 2007, edited by: Solomon, S., Qin, D., Manning, M., Chen, Z., Marquis, M., Averyt, K. B., Tignor, M., and Miller, H. L. Cambridge University Press, Cambridge, UK and New York, NY, USA.

Kalesnik, S. V.: Ocherki glyasiologii (Glaciological essays), Moscow, Ychpedgiz, 182 pp., 1963.

Koreisha, M. M.: Glaciation of Verkhoyansk-Kolyima Region, The USSR Academy of Sciences,Moscow, 143 pp., 1991.

Kotlyakov, V. M. (editor in chief): World Atlas of Snow and Ice Resources, Institute of Geography, RAS, Moscow, 600 pp., 1997.

Krenke, A. N.: Mass exchange in glacier systems on the USSR territory, Leningrad, Hydrometeoizdat, 288 pp., 1982.

Matsumoto, K. Y., Shiraiwa, T., Yamaguchi, S., Sone, T., Nishimira, K., Muravyev, Y. D., Khomentovsky, P. A., and Yamagata, K.: Meteorological observations by automatic weather stations (AWS) in alpine regions of Kamchatka, Russia, 1996-1997, Cryospheric studies in Kamchatka II, Hokkaido University, Sapporo, 155-170, 1999.

Muraviev, Y. D.: Present-day glaciation in Kamchatka - distribution of glaciers and snow, in: Cryospheric studies in Kamchatka II, Institute of Low Temperature Science, Hokkaido University, 17, 1999.

Nakajima, T. and Tanaka, M.: Matrix formulation for the transfer of solar radiation in a plane parallel scattering atmosphere, J. Quant. Spectrosc. Ra., 35, 13-21, 1986.

Shmakin, A. B. and Popova, V. V.: Dynamics of climate extremes in northern Eurasia in the late 20th century, Izvestiya AN, Fizika Atmosfery i Okeana, 42, 157-166, 2006.

Vinogradov, V. N.: Present glaciarization of the areas of active volcanism, Moscow, Nauka, 103, 25 pp., 1975.

Vinogradov, V. N. and Martiyanov, V. L.: Heat balance of Kozelskiy Glacier (Avachnskaya Volcano group), Data Glaciol. Stud., Moscow, 37, 182-187, 1980. 